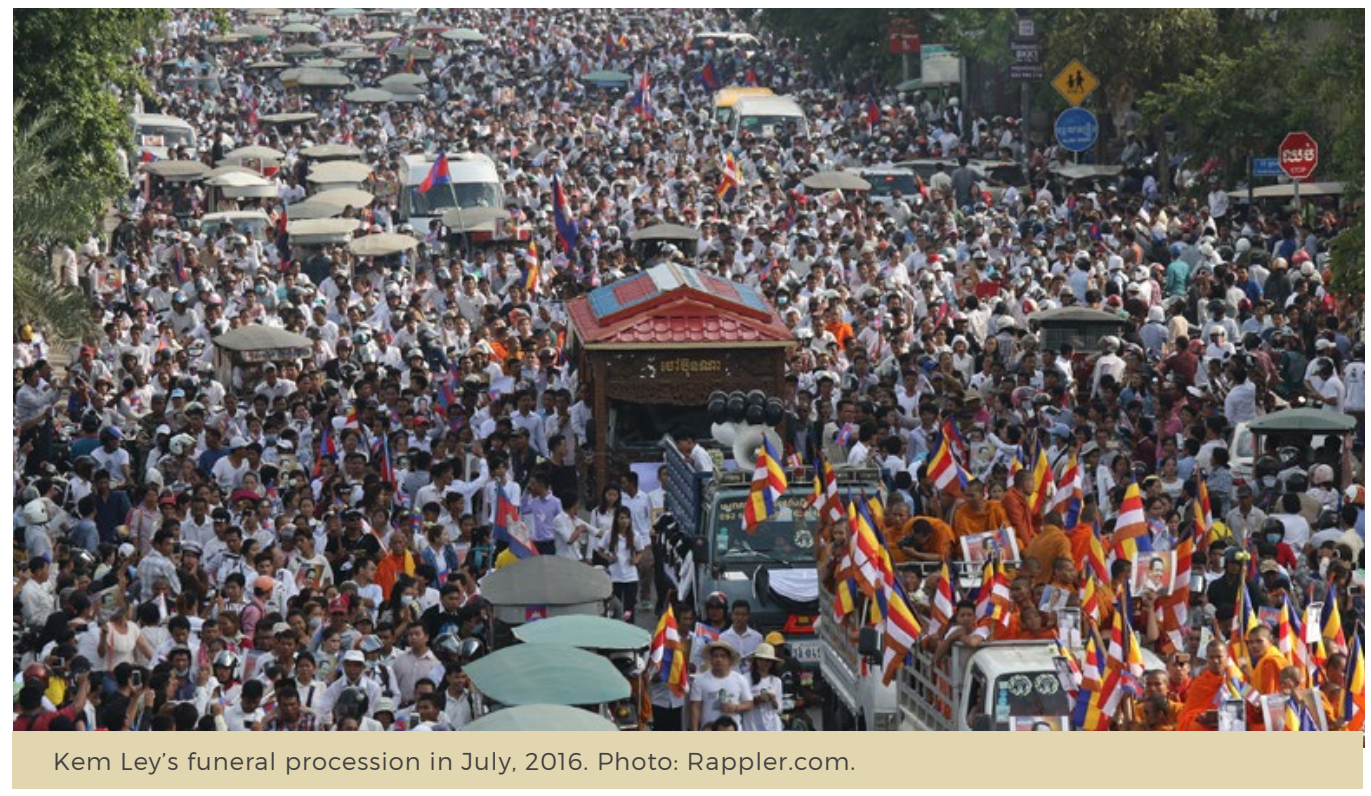

\section{In the Shadow of Kem Ley \\ Is Civil Society the Solution to Cambodia's Woes?}

\section{Astrid Norén-Nilsson}

The assassination of political analyst Kem Ley in Phnom Penh in July 2016 suggests that civil society touches a nerve of great sensibility in today's Cambodia. Cambodian democracy is currently experiencing its tensest period in two decades. If civil society plays a role in this context, it is not primarily within the traditional confines of the associational realm. Rather, in looking for a civil society challenge to party politics, we will have to shift our attention away from NGOs to the tentative emergence of social movements and to the fledgling grassroots democracy movement which Kem Ley himself spearheaded.
On 10 July 2016, independent political analyst and grassroots organiser Kem Ley was shot dead while having his morning coffee at a Caltex petrol station in central Phnom Penh (Ouch and Narim 2016). Two weeks later, an estimated two million people took to the streets to join in his funeral procession (Radio Free Asia 2016). This was the first mass social mobilisation to take place in Cambodia after the early 2014 crackdown, which had reined in the largest anti-government protests in at least fifteen years (Dara and Meyn 2013; Dara and Doyle 2014).

In 2016, Cambodian civil society played a very different role in the making of the mass mobilisations compared to previous demonstrations. In 2013, the unprecedented fearlessness with which ordinary Cambodians took to the streets seemed to be evidence that civil society was entering a new era. Though protesters were motivated by a diverse list of grievances, at that time Cambodia was marked by a sharp polarisation between the incumbent Cambodian People's Party (CPP) and the 
opposition, the Cambodia National Rescue Party (CNRP), with the latter claiming the right to interpret and represent demands for 'change'. On the contrary, in 2016, people came out to pay their respects to a civil society veteran who had sought to radically transform Cambodian politics by reforming both political parties according to civil society principles.

Kem Ley's assassination and subsequent martyrdom suggest that civil society-as an untapped potential-touches a nerve of great sensibility in today's Cambodia. Cambodian democracy is currently experiencing its tensest period in two decades: since the CNRP came within reach of an electoral victory over the CPP in 2013, the two main parties have been locked in a life and death struggle. If civil society plays a role in this context, it is not primarily within the traditional confines of the associational realm. Rather, in looking for a civil society challenge to party politics, we will have to shift our attention away from NGOs, to the tentative emergence of social movements and to the fledgling grassroots democracy movement that Kem Ley spearheaded (Henke 2011).

\section{The Limitations and Possibilities of Cambodian Civil Society}

Ever since their appearance in the early 1990s, Cambodian NGOs have taken on a large share of the functions that typically belong to the state. Still, they have always had to face serious limitations in their work. While recognising the value of the resources and services provided by NGOs for national development, the CPP has circumscribed and undermined NGOs that focus on governance and human rights issues, as well as independent youth organisations and trade unions. Most often, the relationship between the Cambodian state and civil society is understood to be competitive, with the CPP government shaping and restricting the environment in which associational activity can emerge (Feuer et al. 2014; Ly 2014). Others argue instead that the relationship is mutual, with NGOs and other civil society organisations (CSOs) confined to pursuing their objectives through manoeuvrings within the space provided by the state (Waibel et al. 2014).

Accompanying a gradual decline in foreign aid, the Cambodian state is now attempting to restrict the space available to a growing civil society. In August 2015, a highly controversial Law on NGOs and Associations was passed, restricting civil society's right to freedom of association and expression, and enabling the government to shut down organisations that criticise it (HRW 2015). Less than one year later, in April 2016, the Trade Union Law was passed, which provides protection and support to government-backed unions while undermining independent unions (Arbitration Council 2016).

In October 2014, within this stifling overall context, a number of civil society veterans, with Kem Ley at the centre, initiated the 'Khmer for Khmer' advocacy group-a network of civil society leaders and activists who pledged to promote democratic party politics by engaging citizens in the political process. The ambition of the Khmer for Khmer network was to achieve the democratising potential of civil society, not from inside the shrinking space allowed by the state, but by exporting civil society actors and principles to party politics. Their aspiration to bring forward political change via grassroots empowerment represented an extension of the international NGO discourse on empowerment (Calvès 2009).

Kem Ley and his associates reckoned that two decades of the burgeoning NGO sector had produced a huge potential for grassroots leadership-a force that had not yet been felt by the political system. 
Cambodian democratisation, they reasoned, would benefit from inserting civil society leaders into the Cambodian political system. It was with this aim in mind that in August 2015, the founders of the Khmer for Khmer network launched the Grassroots Democracy Party (GDP). The Party was meant to provide an avenue for ordinary Cambodians with good leadership skillstypically civil society leaders-to enter the political field. Significantly, it was not only the initiators and leaders of the GDP who had long-term experience working with NGOs and other CSOs, but also most party rank-and-file activists.

\section{'Grassrootism' as Party Politics?}

The movement for grassroots democracy not only reflects disillusionment with the limitations circumscribing traditional civil society work in Cambodia, but it is also an attempt to break down these constraints by entering the all-important arena of party politics. In this sense, it points to the absolute primacy of party politics for effecting change in Cambodia today. On top of the Khmer for Khmer network's agenda was the creation of microparties around the country-local development parties set up to empower those at the grassroots to become policy-makers. Though these have been slow to take off, the GDP was intended as an umbrella party for one hundred microparties that were to be established.

This suggests that the reintroduction of multi-party politics in Cambodia in 1993 has been a success, to the extent that there is a widespread belief in the country that hope for political change resides in political parties. Still, the grassroots agenda relates uneasily to party politics. Early on, the Khmer for Khmer network denied speculations that it would create its own party, claiming that its mission was only to build and strengthen grassroots political leadership. The group then subtly changed its course with the establishment of the GDP, which was set up to function as an incubator for the practice of 'intraparty democracy'. The aim was to nurture democratic leaders within the political party to work as a team, rather than rely on top leaders. In this sense, 'grassrootism' is a principle that could be emulated by other political parties. Indeed, in my interviews with GDP activists, many have stated that they envisage grassroots mobilisation being taken up by all Cambodian political parties in the future.

Yet, this all-encompassing ambition, which involved the transformation of all political parties, underscores a fundamental ambiguity in the creation of a particular political party vehicle for the grassroots agenda. Upon the creation of the GDP, Kem Ley distanced himself from the new party, only taking on an advisory role similar to the one he maintained for the CNRP. My interviews with his associates suggest that Kem Ley dissociated himself from the GDP precisely because he maintained an aspiration to change the Cambodian political landscape without participating in a specific political party. Kem Ley primarily aspired to be a coordinator among actors: his idea was to connect himself with different groups in society so as to be a focal point for the organisation of change.

Kem Ley aspired to be a charismatic leader who could reach out to, and be accepted by, all different societal groups. This would set him apart from other charismatic political leaders, such as the CNRP's Sam Rainsy and Kem Sokha, who took a partisan, oppositional stance. The ambition to apolitically or consensually represent all of society is a vestige of civil society thinking, and one that eclipses the party political avenue. 


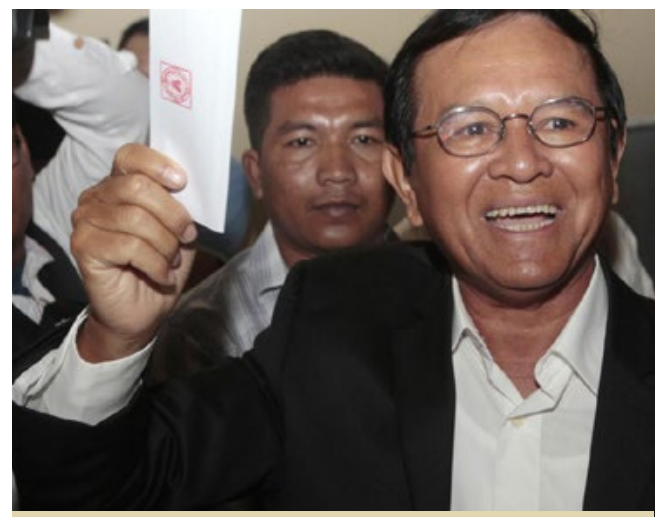

Cambodian opposition leader Kem Sokha was arrested in September 2017. Photo: Yahoo News.

\section{Roads Ahead}

Civil society as an animating idea that transcends the confines of associational life is an important force in today's Cambodia, but one that has not quite found its place. The politicisation of civil society by civil society activists themselves is an attempt to find an outlet for these grassroots energies. A grassroots model of democracy could disrupt the unequal relationships between ordinary citizens and local-level authorities that has been fundamental to the CPP's hold on power, particularly in this context where the existing pattern of local-level politics is already being undermined by demographic change (Hughes 2015). A civil society model of citizenship may be more explosive than that of political opposition.

Yet, ironically, the potential for bottom-up grassroots democracy is so intimately tied to the charismatic leader championing it-Kem Ley-that his assassination has eclipsed its prospects, at least for the time being. Whilst two million Cambodians turned out for Kem Ley's funeral in 2016, the GDP won merely five seats out of more than eleven thousand in the commune elections that took place in 2017. This is not the first time that a massive turnout of Cambodian citizens at the funeral of a beloved, charismatic leader fails to translate into political momentum. At Norodom Sihanouk's funeral procession in February 2013, about one million people poured into the streets to mourn the KingFather (Voice of America Khmer 2013). Yet, in national elections the same year, the royalist party FUNCINPEC for the first time failed to win a single seat, and the party has since all but disintegrated. The lesson is that in Cambodia today charisma is a powerful political force, but political opportunity does not outlive charismatic individuals. The CPP is acutely aware of the potential for charismatic leadership to undermine the party's authority. Since February 2017, five leaders of CNRP have been deposedthree of whom were arrested (Handley 2017). Amendments to the Law on Political Parties in July 2017 have criminalised interaction between parties and convicts, with the aim of erasing individual leaders from the political scene. This has been a largely successful strategy in that it has rendered long-time opposition leader Sam Rainsy less visible on all-important social media, with CNRP activists now afraid to interact with Rainsy's page (Nachemson and Dara 2017). A mere two months later, in September, his substitute Kem Sokha was arrested on charges of treason and now languishes in jail (Zsombor 2017). For what concerns the GDP, the unassuming profiles of its current top troika-Yang Saing Khoma, Sam Inn, and Yeng Virak-put definite limits on the prospects of the fledgling grassroots movement they now lead. Still, civil society sensibilities are evidently close to today's popular aspirations. In such a fragile and tense context dominated by political parties, the dilemma for civil society leaders will be how to rebuild a bridge of intensely felt popular ambitions in the absence of a charismatic leader. 
This text is taken from Gilded Age: A Year of Chinese Labour, Civil Society, and Rights, Made in China Yearbook 2017, edited by Ivan Franceschini and Nicholas Loubere, published 2018 by ANU Press, The Australian National University, Canberra, Australia.

doi.org/10.22459/MIC.04.2018.35 